\title{
Occurrence of non-O157 Shiga toxin-encoding Escherichia coli in artisanal mozzarella cheese in Brazil: risk factor associated with food workers
}

\author{
Patricia CARDOSO ${ }^{1}$, José Moacir MARIN ${ }^{2 *}$
}

\begin{abstract}
Mozzarella cheese is considered a safe food due to the high temperature treatment used in the traditional process of stretching into hot water; however, a post-process contamination during the cheese manufacture or during the processing (before distribution) could occur. This study investigated the occurrence of Shiga toxin-encoding Escherichia coli (STEC) strains in homemade-mozzarella cheese. In total, 59 raw milk cheese samples collected at a local producer in the Jequitinhonha Valley (Northeast of Minas Gerais, Brazil) were submitted for microbiological analysis, and 38 (64.4\%) tested positive for E. coli. Then, 147 strains of $E$. coli were isolated from positive samples and screened by polymerase chain reaction for the presence of the genes encoding the following virulence factors: stx 1 and stx 2 (verotoxin types 1 and 2) and eae (intimin). All the isolates were negative for the stx 2,14 isolates $(9.5 \%)$ were positive for the stx 1 gene, and 11 of them also harbored the eae gene. A food worker was probably involved in cheese contamination during the manufacture schedule. While the development of STEC infection in humans is not completely understood, all STEC- contaminated food can be considered potentially hazardous.
\end{abstract}

Keywords: Escherichia coli; virulence genes; homemade cheese; food handler contamination.

Practical Application: This study demonstrates that mozzarella cheese may be a vehicle for STEC non-O157 strain dissemination among humans, which is a reason for concern due to the high consumption of this cheese by the Brazilian population.

\section{Introduction}

Cheesemaking is a major industry worldwide, and much of it is still practiced on a relatively small scale with only basic hygiene practices (Kousta et al., 2010; Dias et al., 2012). Mozzarella cheese, a typical Italian product, which is also marketed worldwide, was originally prepared from water buffalo milk; however, today, in many countries, some similar products are prepared using bovine or mixed bovine and water buffalo milk. In Minas Gerais (a Brazilian State), bovine milk is commonly used in the manufacture of this cheese (Dias et al., 2012). Artisanal cheeses produced in small processing facilities on dairy farms (farmstead) are manufactured using milk from the farmer's own herd on the farm where the animals are raised. Milk used in the production of farmstead cheese must come from the farmer's own herd and may not be obtained from an outside source. In this case, the food handlers are the owner's family members and/or a small number of employers.

Industrial production of cheeses in Brazil can be accomplished only by using pasteurized milk or with a ripening period of a minimum of 60 days when raw milk is used, and adequate procedures should be followed during all the production steps (Brasil, 1996). However, the production and retail sale of non-inspected dairy products such as homemade cheese is common due to cultural and economic factors (Kousta et al., 2010).
Although mozzarella cheese receives severe heat treatment during curd stretching, some investigators have demonstrated the possibility of a post-heat treatment contamination with organisms originally derived from the manufacturing environments or from cheese markers (Kousta et al., 2010; Dias et al., 2012).

Escherichia coli is commonly present in the intestinal tract of humans and animals, and its detection in processed foods is an indication of fecal matter contamination. It also indicates the inadequate control of the environment of the cheese processing unit, the personal hygiene of the food handlers, and the poor quality of the finished product (Kousta et al., 2010; Dias et al., 2012). Because the occurrence of an outbreak of a foodborne disease is caused by enteropathogenic E. coli and is associated with the consumption of soft ripened cheese (Marier et al., 1973), the presence of these microorganisms in cheese has taken on added significance.

Shiga toxin-producing E. coli (STEC) are among the most important causes of foodborne diseases. They are responsible for several human gastrointestinal diseases, including watery or bloody diarrhea (Paton \& Paton, 1998). The common feature and the primary virulence factor of STEC is the production of Shiga toxin 1 (Stx1), Shiga toxin 2 (Stx2) or its variants, or a combination of these. Highly human-virulent STEC strains are also called enterohemorrhagic E. coli strains (Bolton, 2011). 
Pathogenic STEC strains usually contain other virulence factors such as the outer membrane protein intimin (eae gene), a protein essential for the intimate attachment and formation of attaching and effacing lesions on gastrointestinal epithelial cells (Bolton, 2011). Most outbreaks and sporadic cases of hemorrhagic colitis (HC) and hemolytic uremic syndrome (HUS) have been attributed to strains of serotype O157:H7. However, in some countries, the importance of non-O157 STEC as causes of HUS, HC, and other gastrointestinal disease is being increasingly recognized, particularly the serogroups O26, O103, O111, O121, O45, O145, and O91 (Farrokh et al., 2013).

Food is an important vehicle for the transmission of STEC strains, and most of the foodborne outbreaks caused by STEC have been associated with unpasteurized milk and its derivatives (Farrokh et al., 2013). The aim of this study was to assess the STEC occurrence in the collected cheeses samples.

\section{Materials and methods}

A total of 147 E. coli strains were isolated from artisanal mozzarella cheese obtained from a farm in the Jequitinhonha Valley (Northeast of Minas Gerais, Brazil) in a previous study (Cardoso, 2009). The bacterial isolates were kept at $-20{ }^{\circ} \mathrm{C}$ in Brain Heart Infusion medium (Difco, Becton Dickinson, Sparks, MD, USA) with glycerol 20\% (w/v) in the Laboratory of Genetics, Department of Morphology, Physiology and Basic Pathology, FORP, USP.

In brief, 59 mozzarella cheese samples collected at the producer level during the period of July 2004 to January 2006 were analyzed for the presence of $E$. coli especially STEC strains that were used as indicator organisms for fecal contamination and breaches in hygiene. Every 6 months, 15 cheese samples were collected (one sample was lost, resulting in a total 59 samples) in 2 different days' collection from different batches; for this study, a batch is defined as the cheese produced in 1 day. Cheese samples were transported under refrigeration $\left(4-6^{\circ} \mathrm{C}\right)$ in thermal boxes containing ice packs and were tested immediately after arrival at the laboratory. A $25 \mathrm{~g}$ portion of each cheese was blended with $225 \mathrm{~mL}$ of peptone water (Difco, Detroit USA) for $2 \mathrm{~min}$ at a normal speed using a Stomacher laboratory blender and incubated at $37^{\circ} \mathrm{C}$ for $24 \mathrm{~h}$. Then, $10 \mu \mathrm{l}$ of the culture was streaked onto MacConkey agar (Oxoid, United Kingdom) plates and incubated at $37^{\circ} \mathrm{C}$ for $24 \mathrm{~h}$. At least five colonies from each plate with typical $E$. coli morphology were selected and examined by biochemical tests, including hydrogen sulfide, citrate, urease, and indole (Koneman et al., 1997) to confirm the identification.

The recovered bacterial strains (E. coli isolates) grown overnight in nutrient broth (Sigma Chemical Co, St Louis, USA) at $37^{\circ} \mathrm{C}$ were used for DNA extraction. One $\mathrm{ml}$ of bacterial growth was centrifuged at $10,000 \times \mathrm{g}$ for $1 \mathrm{~min}$. The precipitate was suspended in $100 \mu \mathrm{l}$ of sterile UHQ water, boiled for $10 \mathrm{~min}$, and centrifuged at $10,000 \times \mathrm{g}$ for $2 \mathrm{~min}$. The supernatant was used as the DNA template in the PCR assays. PCR was conducted using the oligonucleotide primers and conditions as described by China et al. (1996) for the detection of stx1, stx 2, and eae genes. The amplified DNA products were analyzed by agarose gel electrophoresis and observed under UV light at a wavelength of
$420 \mathrm{~nm}$ after ethidium bromide staining. Reference E. coli strains used as controls were EDL933 (O157:H7, stx1, stx 2, eae) and $\mathrm{DH} 5 \alpha$ (negative control).

The STEC isolates were typed for the O serogroup O157 using the O157 Latex Agglutination test kit (Oxoid, Basingstoke, UK). The EDL933 strain was used as a positive control. Strains negative for agglutination were considered non-O157 strains.

\section{Results and discussion}

A total of 147 E. coli strains were isolated from 38 mozzarella cheese samples (64.4\%), which were positive for E. coli. All E. coli isolates were investigated by PCR for the presence of Shiga-like toxin-encoding genes (stx 1 and stx 2 ) and the intimin (eae) gene. All STEC strains isolated in this study were tested by the $\mathrm{O} 157$ latex agglutination test, and none $\mathrm{O} 157$ isolate was detected, which is consistent with the results obtained from Brazil with a low frequency of detection of O157 strains (Irino et al., 2005).

As shown in Table 1, 14 (9.5\%) of the strains from five cheese samples (13.1\%) carried the stx gene (all of them carried the $s t x 1$ gene), and 11 isolates among them also harbored the eae gene. It is also important to mention that in Brazil, human STEC infections have been primarily associated with diarrhea and most of the STEC strains isolated are non-O157 strains harboring stx 1 and eae genes (Irino et al., 2007). Pradel et al. (2000) reported the isolation of STEC non-O157 strains from cheese in France, all of them carrying the stxl gene but not the eae gene.

Experimental studies have already shown that treatment at high temperature such as curd stretching at $80^{\circ} \mathrm{C}$ for $5 \mathrm{~min}$ during the manufacture of cow's milk mozzarella cheese has been shown to effectively control STEC strain growth (Spano et al., 2003). In the present study, curd stretching at $75-85^{\circ} \mathrm{C}$ for at least $10 \mathrm{~min}$ was reported by the farmer producer, indicating an efficient heat treatment. Four sample collections were made

Table 1. Virulence gene profiles in non-O157 STEC strains isolated in Brazil from mozzarella cheese.

\begin{tabular}{lccc}
\hline \multirow{2}{*}{ Strains } & \multicolumn{3}{c}{ Virulence gene } \\
\cline { 2 - 4 } & stx 1 & stx 2 & eae \\
\hline $61.4^{*}$ & + & - & + \\
62.1 & + & - & - \\
62.2 & + & - & - \\
62.3 & + & - & + \\
62.5 & + & - & + \\
62.6 & + & - & + \\
62.7 & + & - & + \\
64.1 & + & - & + \\
64.2 & + & - & + \\
64.6 & + & - & + \\
66.8 & + & - & + \\
66.9 & + & - & + \\
66.10 & + & - & + \\
69.3 & + & - & - \\
\hline
\end{tabular}

${ }^{\star} 61.4$ - cheese number 61 , isolate 4 . 
during this study, but all the STEC strains isolated were from the cheese samples obtained in the second collection in January 2005 (data not shown), which occurred coincidentally with the admission by a farm employee at the same cheese production line and later dismissal. The absence of non-O157 STEC isolates from cheeses collected in the others periods was a good indication of the involvement of the abovementioned food worker with the contamination process.

Hoffmann et al. (2014) analyzed 87 E. coli strains isolated from pasteurized milk obtained from 22 farm dairies located at Parana state in Brazil and did not detect the stx1, stx2, and eae virulence genes among the E. coli isolates. Okura \& Marin (2014) examined 330 E. coli strains isolated from 111 Minas frescal cheeses from Southwest Minas Gerais State and also did not detect stx 1, stx 2, or eae genes among the E. coli isolates.

Altekruse et al. (1998) identified 32 cheese-associated outbreaks in the United States, 11 attributed to contamination at the farm, during the manufacture or during processing (before distribution), and 2 among them were associated with eating mozzarella cheese ( 1 improper pasteurization, 1 post-pasteurization contamination). According to Todd et al. (2010), several foodborne outbreak investigation reports have identified the hands of food workers as the source of pathogens in the implicated food. Among them a Center for Disease Control and Prevention (2006) weekly report which reported that during August-September 2005 a total of 52 (2.44\%) of 2,160 inmates at a state correctional facility reported diarrhea, including 17 (33\%) with bloody diarrhea. Sixteen of the samples were positive for stx 1 gene but not for STEC O157 serotyping, and in this case the source of the outbreak likely was an ill food worker.

The identification of the source of contamination was beyond the scope of this study, because we aimed to analyze the potential hazard of the cheese available as a vehicle for the dissemination of diarrheagenic E. coli as it reaches the final customer. However, we made several tentative efforts to get in touch with the employee dismissed, but all of them failed, the employee was dismissed for unknown reasons by the company. Cheese can be easily contaminated by food handlers who practice poor personal hygiene (Kousta et al., 2010) at some point during cheese preparation and/or assembly line. Dias et al. (2012) reported on the implementation of Good Manufacturing Practices (GMP) in a small processing unit of mozzarella cheese in Paraná, Brazil, and that the primary hurdles for the implementation of GMP were related to the difficulties to change the hygiene practices of food handlers.

Research and educational efforts identifying potential on-farm risk factors will better enable dairy producers to reduce/prevent foodborne pathogen contamination of dairy products leaving the farm. Identification of on-farm reservoirs could aid in the implementation of farm-specific pathogen reduction programs. In conclusion, the present study showed the presence of STEC non-O157 strains in mozzarella cheese, which is a reason for concern due to the high consumption of this cheese by the Brazilian population.

\section{Conclusions}

The present study demonstrates the occurrence of non-O157 STEC strains in mozzarella cheese, probably due to a post-heat treatment contamination by a food worker during cheese production.

\section{References}

Altekruse, S. F., Timbo, B. B., Mowbray, J. C., Bean, N. H., \& Potter, M. E. (1998). Cheese-associated outbreaks of human illness in the United States, 1973 to 1992: Sanitary manufacturing practices protect consumers. Journal of Food Protection, 10(10), 1405-1407. PMid:9798166.

Bolton, D. J. (2011). Verocytotoxigenic (Shiga Toxin-producing) Escherichia coli: virulence factors and pathogenicity in the farm to fork paradigm. Foodborne Pathogens and Disease, 8(3), 357-365. http://dx.doi.org/10.1089/fpd.2010.0699. PMid:21114423.

Brasil. Ministério da Agricultura. (1996, Março 7). Aprova os Regulamentos Técnicos de Identidade e Qualidade dos Produtos Lácteos (Portaria n 146, de 7 de março de 1996). Diário Oficial [da] República Federativa do Brasil.

Cardoso, A. C. (2009). Ocorrência de cepas de Escherichia coli isoladas em queijo mussarela produzido artesanalmente (Dissertação de mestrado). Faculdade de Ciências Agrárias e Veterinárias, Universidade Estadual Paulista "Julio de Mesquita Filho", Jaboticabal.

Center for Disease Control and Prevention. (2006). Importance of culture confirmation of Shiga toxin-producing Escherichia coli infection as illustrated by outbreaks of gastroenteritis - New York and North Caroline, 2005. Morbidity and Mortality Weekly Report, 55(38), 1042-1045.

China, B., Pirson, V., \& Mainil, J. (1996). Typing of bovine attaching and effacing Escherichia coli by multiplex in vitro amplification of virulence-associated genes. Applied and Environmental Microbiology, 92(9), 3462-3465. PMid:8795238.

Dias, M. A., Sant'Ana, A. S., Cruz, A. G., Faria, J. A. F., Fernandes de Oliveira, C. A., \& Bona, E. (2012). On the implementation of good manufacturing practices in a small processing unity of mozzarella cheese in Brazil. Food Control, 24(1-2), 199-205. http://dx.doi. org/10.1016/j.foodcont.2011.09.028.

Farrokh, C., Jordan, K., Auvray, F., Glass, K., Oppegaard, H., Raynaud, S., Thevenot, D., Condron, R., De Reu, K., Govaris, A., Heggum, K., Heyndrickx, M., Hummerjohann, J., Lindsay, D., Miszczycha, S., Moussiegt, S., Verstraete, K., \& Cerf, O. (2013). Review of Shigatoxin-producing Escherichia coli (STEC) and their significance in dairy production. International Journal of Food Microbiology, 162(2), 190-212. http://dx.doi.org/10.1016/j.ijfoodmicro.2012.08.008. PMid:22939912.

Hoffmann, S. A., Pieretti, G. G., Fiorini, A., Patussi, E. V., Cardoso, R. F., \& Mikcha, J. M. G. (2014). Shiga-toxin genes and genetic diversity of Escherichia coli isolated from pasteurized cow milk in Brazil. Journal of Food Science, 79(6), M1175-M1180. http://dx.doi. org/10.1111/1750-3841.12477. PMid:24917424.

Irino, K., Kato, M. A. M. F., Vaz, T. M. I., Ramos, I. I., Souza, M. A. C., Cruz, A. S., Gomes, T. A. T., Vieira, M. A. M., \& Guth, B. E. C. (2005). Serotypes and virulence markers of Shiga toxin-producing Escherichia coli (STEC) isolated from dairy cattle in São Paulo State, Brazil. Veterinary Microbiology, 105(1), 29-36. http://dx.doi. org/10.1016/j.vetmic.2004.08.007. PMid:15607081.

Irino, K., Vaz, T. M. I., Medeiros, M. I. C., Kato, M. A. M., Gomes, T. A. T., Vieira, M. A. M., \& Guth, B. E. C. (2007). Serotype diversity as a 
drawback in the surveillance of Shiga toxin-producing Escherichia coli infections in Brazil. Journal of Medical Microbiology, 56(Pt 4), 565-567. http://dx.doi.org/10.1099/jmm.0.46815-0. PMid:17374902.

Koneman, E. W., Allen, S. D., Schrekenberger, P., Janda, C., \& Winn, I. W. C. (1997). Color atlas and textbook of diagnostic microbiology (5th ed.). Philadelphia: Lippincott Company.

Kousta, M., Mataragas, M., Skandamis, P., \& Drosinos, E. H. (2010). Prevalence and sources of cheese contamination with pathogens at farm and processing levels. Food Control, 21(6), 805-815. http:// dx.doi.org/10.1016/j.foodcont.2009.11.015.

Marier, R., Wells, J. G., Swanson, R. C., Callahan, W., \& Mehlman, I. J. (1973). An outbreak of enteropathogenic Escherichia coli foodborne disease traced to imported French cheese. Lancet, 2(7842), 13761378. http://dx.doi.org/10.1016/S0140-6736(73)93335-7.

Okura, M. H., \& Marin, J. M. (2014). Survey of Minas frescal cheese from Southwest Minas Gerais for virulence factors and antimicrobial resistance in Escherichia coli isolates. Ciência Rural, 44(8), 1506-1511. http://dx.doi.org/10.1590/0103-8478cr20131237.
Paton, J. C., \& Paton, A. W. (1998). Pathogenesis and diagnosis of Shiga toxin-producing Escherichia coli infection. Clinical Microbiology Reviews, 11(3), 450-479. PMid:9665978.

Pradel, N., Livrelli, V., De Champs, C., Palcoux, J. B., Reynaud, A., Scheutz, F., Sirot, J., Joly, B., \& Forestier, C. (2000). Prevalence and characterization of Shiga toxin-producing Escherichia coli isolated from cattle, food, and children during a one-year prospective study in France. Journal of Clinical Microbiology, 38(3), 1023-1031. PMid:10698990.

Spano, G., Goffredo, E., Beneduce, L., Tarantino, D., Dupuy, A., \& Massa, S. (2003). Fate of Escherichia coli O157:H7 during the manufacture of Mozzarela cheese. Letters in Applied Microbiology, 36(2), 73-76. http://dx.doi.org/10.1046/j.1472-765X.2003.01252.x. PMid:12535124.

Todd, E. C. D., Michaels, B. S., Smith, D., Greig, J. D., \& Bartleson, C. A. (2010). Outbreaks where food workers have been implicated in the spread of foodborne disease. Part 9. Washing and drying of hands to reduce microbial contamination. Journal of Food Protection, 73(10), 1937-1955. PMid:21067683. 